\title{
Міні-інвазивне багатосудинне коронарне шунтування в умовах штучного кровообігу: аналіз ранніх результатів та опанування методики
}

\author{
Бабляк О.Д., Дем’яненко В. М., Мельник Є. А., Ревенко К. А., Підгайна Л. В., \\ Стогов О. С.
}

Кардіохірургічний центр ММ «Добробут» (Київ)

\begin{abstract}
Мета роботи - проаналізувати ранні результати даної методики порівняно із загальноприйнятою методикою аортокоронарного шунтування в умовах штучного кровообігу, а також оцінити рівень опанування методики міні-інвазивного коронарного шунтування в умовах штучного кровообігу на основі порівняння хірургічного досвіду перших 30 послідовних прооперованих пацієнтів із 30 наступними.

Матеріали та методи. Проаналізовано дані 60 послідовно прооперованих пацієнтів за методикою міні-інвазивного коронарного шунтування в умовах штучного кровообігу за період із липня 2017 року по лютий 2018 року та 30 послідовно прооперованих пацієнтів за загальноприйнятою методикою аортокоронарного шунтування в умовах штучного кровообігу за період із січня 2017 року по червень 2017 року.

Результати та обговорення. За період дослідження не було летальних випадків, значних ускладнень та ревізії післяопераційної рани з приводу кровотечі. Конверсія до серединної стернотомії відсутня в обох групах міні-інвазивного багатосудинного коронарного шунтування.

Час операції у групі пізнього досвіду зменшився і склав $247,8 \pm 37,3$ хв. порівняно з $276,2 \pm 48,5$ хв. у групі раннього досвіду, $p<0,05$. Час операції, час штучного кровообігу був статистично значущо більшим у групі пізнього досвіду $-247,8 \pm 37,3$ хв. та $131 \pm 26,5$ хв. на противагу $222 \pm 28$ хв. та 93, $1 \pm 20,8$ хв. у групі серединної стернотомії, $\mathrm{p}<0,05$.

Тривалість госпіталізації скоротилася у групі пізнього досвіду $-5,6 \pm 1,1$ днів порівняно із серединною стернотомією $-6,7 \pm 1,2$ днів, $\mathrm{p} \leq 0,001$.

Висновки. Міні-інвазивне багатосудинне коронарне шунтування в умовах штучного кровообігу є безпечним та ефективним методом хірургічного лікування IXC. За час впровадження та освоєння методики не було летальних випадків і великих післяопераційних серцевих ускладнень. Досвід 30 операцій є достатнім для опанування методики, щоб основні інтраопераційні показники збігалися з результатами при стандартній методиці аортокоронарного шунтування через серединну стернотомію. Час перебування в стаціонарі в групі міні-інвазивного шунтування менший порівняно з групою серединної стернотомії.
\end{abstract}

Ключові слова: ішемічна хвороба серия, коронарне шунтування, міні-інвазивне багатосудинне коронарне шунтування.

Кардіохірургічні операції в еру новітніх технологій усе частіше асоціюються з міні-інвазивними втручаннями. Операції при ізольованих клапанних вадах серця в рутинній практиці провідних світових кардіохірургічних центів перейшли в розділ міні-інвазивних або інтервенційних втручань. Ця тенденція стосується і коронарного шунтування $[1,2]$. Запропоновані та описані в публікаціях методи міні-інвазивного багатосудинного коронарного шунтування [3-7] дозволяють провести повну реваскуляризацію міокарда. Дані методики не набули значного поширення серед кардіохірургів через велику тривалість операції, складність та обмеження в методах $[8,9]$.

Із липня 2017 року в нашій установі розроблена та впроваджена методика міні-інвазивного багатосудинного коронарного шунтування в умовах штучного кровообі- гу [10], яка наразі залишається для нас методикою вибору при необхідності проведення коронарного шунтування.

Мета роботи - проаналізувати ранні результати даної методики порівняно із загальноприйнятою методикою аортокоронарного шунтування в умовах штучного кровообігу, оцінити рівень опанування методики міні-інвазивного коронарного шунтування в умовах штучного кровообігу на основі порівняння досвіду перших 30 послідовних пацієнтів із 30 наступними.

Матеріали та методи. Нами проаналізовано дані 60 послідовно прооперованих пацієнтів за методикою міні-інвазивного коронарного шунтування в умовах штучного кровообігу за період з липня 2017 року по лютий 2018 року. Було сформовано дві групи пацієнтів: 1 група «Ранній досвід» - від 1-го до 30 пацієнта, 2 група «Пізній досвід» - від 31 до 60 пацієнта. Для порів- 
няння результатів даної методики була включена група «Серединна стернотомія» із 30 послідовних пацієнтів, прооперованих за стандартною методикою коронарного шунтування зі серединною стернотомією за період із січня 2017 року по червень 2017 року.

За даними коронарографії в усіх пацієнтів був діагностований стенозуючий атеросклероз коронарних артерій у декількох басейнах.

Методика операції міні-інвазивного багатосудинного коронарного шунтування, описана нами раніше [10], була використана при операціях у пацієнтів обох міні-інвазивних груп.

Всім пацієнтам до операції проводилися такі обстеження: електрокардіографія, ехокардіографія, коронарографія, дуплекс-допплерографія судин нижніх кінцівок і каротидних артерій. Пацієнтам, яких оперували через міні-інвазивний доступ, проводилась комп'ютерна томографія грудного та черевного відділу з внутрішньовенним контрастуванням. При наявності хронічних обструктивних захворювань легень проводили спірометрію.

Похилий вік, наявність цукрового діабету, ургентна операція, погана якість або малий розмір коронарних судин (за даними ангіографії), тяжкість стенокардії, знижена фракція викиду (ФВ) лівого шлуночка, серцева недостатність, атеросклероз черевної аорти та артерій нижніх кінцівок не вважалися нами протипоказаннями до операції міні-інвазивного багатосудинного коронарного шунтування в умовах штучного кровообігу.

Для аналізу рівня опанування даної методики нами було обрано такі хірургічні критерії: тривалість операції, час перетиснення аорти, тривалість штучного кровообігу, кількість коронарних анастомозів і відсоток артеріальних кондуїтів. Для оцінки ранніх результатів методики зазначені вище критерії порівнювалися з такими ж критеріями при загальноприйнятій методиці аортокоронарного шунтування в умовах штучного кровообігу

Результати та обговорення. За період дослідження не було летальних випадків, великих післяопераційних серцевих ускладнень та ревізії післяопераційної рани з приводу кровотечі. Конверсія до серединної стернотомії відсутня в обох групах міні-інвазивного багатосудинного коронарного шунтування. Спостерігався один післяопераційний інсульт без залишкового неврологічного дефіциту в групі раннього досвіду

\section{Таблиця 1}

Демографічна, операційна та післяопераційна характеристика груп раннього та пізнього досвіду

\begin{tabular}{|c|c|c|c|c|}
\hline & $\begin{array}{c}\text { Міні-інвазивне коронарне } \\
\text { шунтування }\end{array}$ & Ранній досвід & Пізній досвід & P value \\
\hline \multicolumn{5}{|l|}{ Демографічні показники } \\
\hline Вік, роки & $62,3 \pm 9,5$ & $60,4 \pm 8,6$ & $64,1 \pm 10,1$ & $0,035^{*}$ \\
\hline Вага, кг & $89,9 \pm 11,4$ & $90,1 \pm 10,7$ & $89,7 \pm 12,3$ & 0,790 \\
\hline Зріст, см & $171,9 \pm 6,4$ & $171,8 \pm 6,7$ & $171,9 \pm 6,1$ & 0,733 \\
\hline BSA, $M^{2}$ & $2,1 \pm 0,2$ & $2,1 \pm 0,1$ & $2,1 \pm 0,2$ & 0,953 \\
\hline $\mathrm{BMI}, \mathrm{K} \Gamma / \mathrm{M}^{2}$ & $30,4 \pm 3,5$ & $30,5 \pm 3,4$ & $30,3 \pm 3,6$ & 0,918 \\
\hline Жіноча стать & $7(11,7 \%)$ & $3(10 \%)$ & $4(13,3 \%)$ & 0,688 \\
\hline \multicolumn{5}{|l|}{ Операційні показники } \\
\hline $\begin{array}{l}\text { Загальна кількість } \\
\text { анастомозів }\end{array}$ & $3,28 \pm 0,76$ & $3,43 \pm 0,82$ & $3,13 \pm 0,68$ & 0,173 \\
\hline $\begin{array}{l}\text { Кількість артеріальних } \\
\text { анастомозів }\end{array}$ & $1,65 \pm 1,16$ & $1,7 \pm 1,15$ & $1,6 \pm 1,19$ & 0,442 \\
\hline $\begin{array}{l}\text { Кількість венозних } \\
\text { анастомозів }\end{array}$ & $1,63 \pm 1,08$ & $1,73 \pm 1,17$ & $1,53 \pm 1$ & 0,438 \\
\hline Час операції, хв. & $262 \pm 45,2$ & $276,2 \pm 48,5$ & $247,8 \pm 37,3$ & $0,018^{*}$ \\
\hline Час перетиснення аорти, хв. & $72,7 \pm 20,4$ & $76,5 \pm 20,2$ & $68,9 \pm 20,1$ & 0,104 \\
\hline Час штучного кровообігу, хв. & $136,8 \pm 32,4$ & $142,6 \pm 36,9$ & $131 \pm 26,5$ & 0,183 \\
\hline \multicolumn{5}{|l|}{ Післяопераційний перебіг } \\
\hline Час ШВЛ, год. & $6,0 \pm 11,9$ & $7,2 \pm 15,4$ & $4,7 \pm 7,1$ & 0,130 \\
\hline Перебування в ПІТ, ночі & $2,4 \pm 1$ & $2,5 \pm 1,2$ & $2,2 \pm 0,7$ & 0,276 \\
\hline Час госпіталізації, дні & $5,8 \pm 1,3$ & $5,9 \pm 1,5$ & $5,6 \pm 1,1$ & 0,329 \\
\hline Ексудація за 12 годин, мл & $445,8 \pm 189,6$ & $430,8 \pm 171,2$ & $460,8 \pm 208,2$ & 0,739 \\
\hline
\end{tabular}

* Різниця щодо показників статистично значуща $(\mathrm{p}<0,05)$ 
міні-інвазивного багатосудинного коронарного шунтування.

Для оцінки рівня опанування методики наведена порівняльна характеристика групи раннього та пізнього досвіду (табл. 1).

При порівнянні групи раннього та пізнього досвіду з'ясувалося, що за демографічними показниками різниця групах є тільки за віком: $60,4 \pm 8,6$ років у групі раннього досвіду та $64,1 \pm 10,1$ років у групі пізнього досвіду, $\mathrm{p}<0,05$.

Час операції у групі пізнього досвіду зменшився і склав $247,8 \pm 37,3$ хв. порівняно з $276,2 \pm 48,5$ хв. у групі ранній досвіду, $\mathrm{p}<0,05$, при цьому час перетиснення аорти та час штучного кровообігу статистично значущо не відрізнявся. Післяопераційні показники не мали статистично достовірної різниці в обох групах.

\section{Таблиця 2}

Демографічна, операційна та післяопераційна характеристика груп «серединна стернотомія» та «nізній досвід»

\begin{tabular}{lccc} 
& $\begin{array}{c}\text { Серединна } \\
\text { стернотомія }\end{array}$ & $\begin{array}{c}\text { Пізній } \\
\text { досвід }\end{array}$ & P -value \\
\hline Демографічні показники & & \\
\hline Вік, роки & $63,3 \pm 8,9$ & $64,1 \pm 10,1$ & 0,428 \\
\hline Вага, кг & $83,7 \pm 14,1$ & $89,7 \pm 12,3$ & 0,176 \\
\hline Зріст, см & $166,3 \pm 9,5$ & $171,9 \pm 6,1$ & 0,117 \\
\hline ВSА, м & $1,9 \pm 0,2$ & $2,1 \pm 0,2$ & 0,070 \\
\hline ВМІ, кг/м ${ }^{2}$ & $30,4 \pm 4,9$ & $30,3 \pm 3,6$ & 0,620 \\
\hline Жіноча стать & $10(33,3 \%)$ & $4(13,3 \%)$ & 0,067 \\
\hline
\end{tabular}

Операційні показники

\begin{tabular}{|c|c|c|c|}
\hline $\begin{array}{l}\text { Загальна кількість } \\
\text { анастомозів }\end{array}$ & $3,5 \pm 0,82$ & $3,13 \pm 0,68$ & 0,107 \\
\hline $\begin{array}{l}\text { Кількість } \\
\text { артеріальних } \\
\text { анастомозів }\end{array}$ & $1,8 \pm 0,88$ & $1,6 \pm 1,19$ & 0,136 \\
\hline $\begin{array}{l}\text { Кількість венозних } \\
\text { анастомозів }\end{array}$ & $1,7 \pm 1,23$ & $1,53 \pm 1$ & 0,794 \\
\hline Час операції, хв & $222 \pm 28$ & $247,8 \pm 37,3$ & $0,015^{*}$ \\
\hline $\begin{array}{l}\text { Час перетиснення } \\
\text { аорти, хв }\end{array}$ & $71 \pm 20,1$ & $68,9 \pm 20,1$ & 0,631 \\
\hline $\begin{array}{l}\text { Час штучного } \\
\text { кровообігу, хв }\end{array}$ & $93,1 \pm 20,8$ & $131 \pm 26,5$ & $0,001^{*}$ \\
\hline \multicolumn{4}{|c|}{ Післяопераційний перебіг } \\
\hline Час ШВЛ, год & $4,8 \pm 2$ & $4,7 \pm 7,1$ & 0,201 \\
\hline $\begin{array}{l}\text { Перебування в } \\
\text { ПIT, ночі }\end{array}$ & $2,1 \pm 0,3$ & $2,2 \pm 0,7$ & 0,395 \\
\hline $\begin{array}{l}\text { Час госпіталізації, } \\
\text { дні }\end{array}$ & $6,7 \pm 1,2$ & $5,6 \pm 1,1$ & $0,001^{*}$ \\
\hline $\begin{array}{l}\text { Ексудація за } 12 \\
\text { годин, мл }\end{array}$ & $219,2 \pm 107,1$ & $460,8 \pm 208,2$ & $0,001^{*}$ \\
\hline
\end{tabular}

* Різниця щодо показників статистично значуща $(\mathrm{p}<0,05)$
Результати порівняльної характеристики показників груп серединної стернотомії та пізнього досвіду наведено в табл. 2.

Як видно з табл. 2, при порівнянні груп «серединна стернотомія» та «пізній досвід» за демографічними показниками статистично достовірної різниці виявлено не було. Групи не відрізнялися за кількістю коронарних анастомозів і відсотком артеріальних кондуїтів. Час операції, час штучного кровообігу був статистично значущо більшим у групі пізнього досвіду $-247,8 \pm 37,3$ хв. та $131 \pm 26,5$ хв. на противагу $222 \pm 28$ хв. та 93,1 $\pm 20,8$ хв. у групі серединної стернотомії, $\mathrm{p}<0,05$.

Тривалість госпіталізації скоротилася у групі пізнього досвіду $(5,6 \pm 1,1$ днів) порівняно із групою серединної стернотомії (6,7 $\pm 1,2$ днів), $\mathrm{p} \leq 0,001$.

Ексудація статистично достовірно була меншою у групі серединної стернотомії - 219,2 $\pm 107,1$ мл порівняно з 460,8 $\pm 208,2$ мл у групі пізнього досвіду, $\mathrm{p} \leq 0,001$.

Висновки. Міні-інвазивне багатосудинне коронарне шунтування в умовах штучного кровообігу є безпечним та ефективним методом хірургічного лікування IXC.

За час впровадження та освоєння методики не було летальних випадків і великих післяопераційних серцевих ускладнень.

Досвід, отриманий на матеріалі перших 30 пацієнтів, дозволив зменшити операційні параметри (тривалість операції, час перетиснення аорти та тривалість штучного кровообігу) у наступних 30 пацієнтів і наблизити операційні параметри до відповідних при коронарному шунтуванні за стандартною методикою серединної стернотомії.

Час перебування пацієнтів у стаціонарі в групі мініінвазивного багатосудинного коронарного шунтування є меншим порівняно з відповідними показниками групи серединної стернотомії.

Вибір методики міні-інвазивного багатосудинного коронарного шунтування в умовах штучного кровообігу не впливає на кількість коронарних анастомозів і відсоток артеріальних кондуїтів.

\section{Лiтература}

1. The golden age of minimally invasive cardiothoracic surgery: current and future perspectives / Iribarne A., Easterwood R., Chan E. et al. // Future Cardiology. 2011. - Vol. 7 (3). - P. 333-346.

2. Langer, N. and Argenziano, M. (2016). Minimally Invasive Cardiovascular Surgery: Incisions and Approaches // Methodist DeBakey Cardiovascular Journal. - 2016. Vol. 12 (1). - P. 4-9.

3. Port-access coronary artery bypass grafting: technique and comparative results / Groh M. A., Sutherland S. E., Burton H. G. et al. // Ann Thorac Surg. - 1999. - Vol. 68 (4). - P. 1506-1508. 
4. The Dresden approach for complete multivessel revascularisation / Gulielmos V., Brandt M., Knaut M. et al. // Ann Thorac Surg. - 1999. - Vol. 68. - P. 1502-5.

5. Minimally invasive coronary artery bypass grafting: dual-center experience in 450 consecutive patients / McGinn J. T. Jr., Usman S., Lapierre H. et al. // Circulation. - 2009 Sep 15. - Vol. 120 (11 Suppl). S78-84.

6. Minimally invasive cardiac surgery coronary artery bypass grafting (MICS CABG): a review of technique and literature / Guo M., Rodriguez M. and Ruel M. / Indian Journal of Thoracic and Cardiovascular Surgery. - 2017. Vol. 12 (1). - P. 4-9.

7. Left anterior small thoracotomy for minimally invasive coronary artery bypass grafting / D. Reser, T. Holubec, E. Caliskan et al. // Multimedia Manual of CardioThoracic Surgery. - 23 August 2015.
8. Minimally invasive coronary artyery bypass grafting: the mid-term outcomes and learning curve effect / Rodriguez M., Lapierre H., Sohmer B. et al. // Canadian Journal of Cardiology. - 2016. - Vol. 32 (10). - P. 106.

9. Does minimally invasive coronary artery bypass improve outcomes compared to off-pump coronary bypass via sternotomy in patients undergoing coronary artery bypass grafting? / Florisson D., DeBono J., Davies R. and Newcomb A. // Interactive CardioVascular and Thoracic Surgery, $2018-$ P. 1-8.

10. Бабляк О. Д., Дем'яненко В. М. Міні-інвазивне багатосудинне коронарне шунтування в умовах передньолатеральної торакотомії // Серце і судини. - 2018. № 1 (61). - C. 65-69.

\title{
Minimally invasive multivessel coronary artery bypass grafting. Analysis of early results and mastery of technique
}

\author{
Babliak O. D., Demyanenko V. M., Melnyk E. A., Revenko K. A., Pidgaina L. V., Stohov A. S. \\ Cardiosurgery Center of Dobrobut Health Care Network
}

To analyze the early results of this technique in comparison with the generally accepted method of coronary artery bypass grafting in conditions of cardio-pulmonary bypass. To evaluate the mastering of technique of minimally invasive coronary artery bypass grafting in conditions of cardio-pulmonary bypass based on the comparison of the experience of the first 30 consecutive patients with the following 30 .

Materials and methods. The data of 60 sequentially patients undergoing the procedure of minimally invasive coronary artery bypass grafting in the period from July 2017 to February 2018 and 30 consecutive patients operated according to the standard method of coronary artery bypass grafting with cardio-pulmonary bypass for the period from January 2017 to June 2017 year.

Results and discussion. During the study period, there were no mortality, no major complications, and no revision for postoperative bleeding. Conversion to median sternotomy is absent in both groups of minimally invasive multivessel coronary artery bypass grafting.

Time of operation in the group of late experience decreased and amounted to $247.8 \pm 37.3$ min compared with $276.2 \pm 48.5$ $\min$ in the group of early experience, $\mathrm{p}<0,05$. The time of operation, the time of cardio-pulmonary bypass was statistically significantly higher in the late experience group of $247.8 \pm 37.3 \mathrm{~min}$ and $131 \pm 26.5 \mathrm{~min}$ in contrast to $222 \pm 28 \mathrm{~min}$ and $93.1 \pm 20.8 \mathrm{~min}$ in the median sternotomy group, $\mathrm{p}<0.05$.

The length of stay in the hospital was reduced in the group of late experience $5.6 \pm 1.1$ days in comparison with median sternotomy $6.7 \pm 1.2$ days, $\mathrm{p} \leq 0.001$.

Conclusions. Minimally invasive multivessel coronary artery bypass grafting is a safe and effective method of surgical treatment of coronary artery disease. During the implementation and development of the method, there were no mortality, no major complications. The detection of the technique is within the range of 30 patients, after which the main operating parameters are approaching the corresponding with median sternotomy. The length of stay in the hospital in the group of minimally invasive bypass surgery is less in comparison with the group of median sternotomy.

Key words: ischemic heart disease, coronary artery bypass grafting, minimally invasive multivessel coronary artery bypass grafting. 